\title{
Vitamin D receptor gene Apal and Fokl polymorphisms and its association with inflammation and oxidative stress in vitamin D sufficient Caucasian Spanish children
}

\author{
Sara Ferrer-Suay ${ }^{1}$, Eulalia Alonso-Iglesias ${ }^{2}$, Miguel Tortajada-Girbés ${ }^{1,3}$, Joaquín Carrasco-Luna ${ }^{1,4}$, \\ Pilar Codoñer-Franch ${ }^{1,3} \wedge$
}

${ }^{1}$ Department of Pediatrics, Obstetrics and Gynecology, University of Valencia, Valencia, Spain; ${ }^{2}$ Department of Biochemistry and Molecular Biology, University of Valencia, Valencia, Spain; '3ervice of Pediatrics, University Hospital Doctor Peset, Foundation for Promotion of Health and Biomedical Research in the Valencian Region (FISABIO), Valencia, Spain; ${ }^{4}$ Department of Experimental Sciences, Catholic University of Valencia, Valencia, Spain

Contributions: (I) Conception and design: P Codoñer-Franch; (II) Administrative support: P Codoñer-Franch; (III) Provision of study materials or patients: J Carrasco Luna, S Ferrer-Suay, M Tortajada-Girbés; (IV) Collection and assembly of data: J Carrasco-Luna, S Ferrer-Suay, E AlonsoIglesias; (V) Data analysis and interpretation: All authors; (VI) Manuscript writing: All authors; (VII) Final approval of manuscript: All authors.

Correspondence to: Pilar Codoñer-Franch. Department of Pediatrics University Hospital Dr. Peset. Avenida Gaspar Aguilar 90, 46017 Valencia, Spain. Email: pilar.codoner@uv.es.

Background: Vitamin D has gone from being just one vitamin to being an important prohormone with multiple effects on different tissue types. The mechanism of action of the active form or calcitriol is mediated by the intracellular vitamin D receptor (VDR). The interaction of the VDR with calcitriol modulates the expression of target genes involved in cell proliferation and cytokine production. Several studies have explored the effects of vitamin D deficiency in inflammatory disorders. Furthermore, some mutations in the $V D R$ can affect its functionality. The focus of this study was to explore associations between $V D R$ single nucleotide polymorphisms (SNPs) and markers of inflammation and oxidative stress in vitamin D sufficient children.

Methods: This is a cross-sectional study of a Caucasian Spanish population including 155 healthy children (87 males, 68 females) aged 10 to 14 years. FokI, ApaI and TaqI SNPs of the VDR gene were genotyped. Routine biochemistry, serum levels of interleukin-6, tumor necrosis factor- $\alpha$, interferon- $\gamma, 8$-isoprostaglandin F2 $\alpha$ and nitrates were determined.

Results: The homozygous major allele AA in the FokI SNP was associated with increased levels of highdensity lipoprotein cholesterol in a recessive inheritance mode $(\mathrm{P}=0.025)$. The minor allele A of ApaI was significantly associated with decreased serum tumor necrosis factor- $\alpha$ and 8 -isoprostaglandin F2 $\alpha$ in an additive mode $(\mathrm{P}=0.016$ and $\mathrm{P}=0.020$ respectively). No significant associations were observed between the TaqI SNP and any of the parameters evaluated. Haplotype analysis confirmed the significance of the relationships between ApaI and FokI SNPs and parameters associated with inflammation and oxidative stress. Conclusions: Genetic variations of $V D R$ are associated with subtle changes in metabolic, inflammatory and oxidative stress markers. These results may provide a better understanding of the relationships between vitamin $\mathrm{D}$ and these clinical parameters.

Keywords: Biomarkers; inflammation; oxidative stress; $V D R$ polymorphisms and vitamin D

Submitted Jul 17, 2020. Accepted for publication Nov 06, 2020.

doi: $10.21037 / \mathrm{tp}-20-198$

View this article at: http://dx.doi.org/10.21037/tp-20-198

$\wedge$ ORCID: 0000-0002-1549-1573. 


\section{Introduction}

Vitamin D has prominent physiologic roles that are not limited to calcium-phosphorus homeostasis and bone turnover. It has been characterized as an important prohormone with multiple actions associated with various immunological and inflammatory processes $(1,2)$. Biological activities of vitamin $\mathrm{D}$ include regulation of gene expression at the transcriptional level that involve binding of its active form (1,25-dihydroxycholecalciferol) to the vitamin D receptor (VDR) located in the nucleus of the target cells (3). VDR is a ligand-dependent transcription factor, a member of the steroid/thyroid hormone receptor superfamily that transactivates genes involved in proliferation, differentiation and activation of immune cells as well as cytokine production. VDR is widely expressed in body tissues; as such, functional alterations may have critical repercussions with respect to vitamin D-associated responses. Similarly, genetic variations in the VDR gene (ID: 7421) can influence receptor structure, its capacity to interact with vitamin $\mathrm{D}$, downstream signaling and function (4-7) as well as susceptibility to disease. Numerous single nucleotide polymorphisms (SNPs) associated with the VDR gene have been documented $(8,9)$. The most frequently studied SNPs include FokI A>G (rs2228570) which is located in exon 2, ApaI C>A (rs7975232) located in intron 8, and TaqI A>G (rs731236) located in exon 9. The FokI polymorphism is found near the 5' untranslated region within the VDR DNAbinding domain; TaqI and ApaI polymorphisms are closer to the 3 ' untranslated region (10). The untranslated regions play an essential role in mediating mRNA stability and posttranscriptional processing. These polymorphisms have been associated to tumorigenesis (11) metabolic profile (12) and immune response (13).

In addition, vitamin $\mathrm{D}$ is a controller of chronic inflammation and oxidative stress (14) closely related to the occurrence and development of many chronic conditions such as cardiovascular disease and other degenerative processes (15). The potential mechanisms by which vitamin $\mathrm{D}$ exert the biological actions are linked to the key redox agent glutathione and regulated by epigenetic modifications (16-18).

Status of vitamin $\mathrm{D}$ is of great concern in critical periods of growth, mainly in the pubertal spurt $(19,20)$. To the date, most of the studies focused on VDR have been performed in subjects who are vitamin D-deficient because VDR SNPs may modify receptor-mediated responses based on vitamin D status (21). Scarce data are available for vitamin D sufficient subjects (19). We carried out this study in healthy children and adolescents aged 10 to 14 years with sufficient levels of vitamin $\mathrm{D}$ to examine the relationships between FokI, ApaI and TaqI SNPs in the VDR gene and parameters of inflammation and oxidative stress. Our objective was determinate whether the presence of these SNPs may be involved in the mechanisms of degenerative processes in adulthood such as cardiovascular disease.

We present the following article in accordance with the Materials Design Analysis Reporting (MDAR) checklist (available at http://dx.doi.org/10.21037/tp-20-198).

\section{Methods}

\section{Study population}

We conducted a cross-sectional study in a Caucasian Spanish population of consecutive recruited 155 children and adolescents of both sexes ( 87 males, 68 females) between the ages of 10-14 years. They were referred by their primary care pediatrician to the outpatient Pediatric Nutrition Unit of University Hospital Dr. Peset (Valencia, Spain) for health checks and/or family studies of hypercholesterolemia or celiac disease, among other conditions between December 2017 and October 2018. Only those children with normal nutritional status who were undergoing blood extraction as a part of their standard clinical protocol were recruited. Levels of vitamin D (25-hydroxycholecalciferol) should be in the sufficient range $(\geq 50 \mathrm{nmol} / \mathrm{L})(22-24)$. None of the children had acute infectious illnesses, were taking vitamin supplements or were engaged in frequent or vigorous physical activity. The children resided on the Spanish Mediterranean coast at latitude of $39^{\circ} 28^{\prime} 48^{\prime \prime}$, in a region with a mean of 2,660 hours of sunlight per year. Written consent for inclusion in the study was obtained from parents and/or guardians and/or children $>12$ years. The study was conducted in accordance with the Declaration of Helsinki (as revised in 2013) and it has the approval of the ethical committee for clinical research of the Hospital (approval number CEIC 27/12).

\section{Biochemical determinations}

Routine biochemical tests were performed in blood samples obtained after a 12 -hour fasting period using peripheral venipuncture methods. Parameters evaluated included serum glucose, total cholesterol, and high-density lipoprotein cholesterol (HDL-C) that were measured by 
photometric automated techniques in self-analyzers (Abbot Architect c16000; Abbott Clinical Chemistry Abbott Park, IL, USA). SerumVitamin D (25-hydroxycholecalciferol) was quantified by electrochemiluminescence immunoassay in the Roche COBAS 6000 autoanalyzer (Roche Diagnostics GmbH, Mannheim, Germany).

\section{Inflammatory markers}

Serum levels of tumor necrosis factor- $\alpha$ (TNF- $\alpha$ ), interleukin-6 and interferon- $\gamma$ were determined by a multiplexed method using Luminex Map Technology LabScan 100 system (Luminex, Austin, TX, USA) and the Milliplex MAP human high sensitivity $\mathrm{T}$ cell panel-immunology multiplex assay catalog number HSTCMAG-28 SK. TNF- $\alpha$ inter- and intra-assay coefficient of variation (CV) were $<20 \%$ and $10 \%$ respectively; interleukin-6 inter- and intra-assay $\mathrm{CV}$ were $<15 \%$ and $<10 \%$ respectively; INF- $\gamma$ inter- and intra-assay CV were $<20 \%$ and $<5 \%$ respectively. Sensitivity was between 0.11 to $8.17 \mathrm{pg} / \mathrm{mL}$ and accuracy $98-107 \%$.

\section{Oxidative stress parameters}

8-isoprostaglandin $\mathrm{F} 2 \alpha$ (8-iso-PGF $2 \alpha$ ) and nitrates were measured as markers of oxidative stress. Serum levels of 8 -iso-PGF2 $\alpha$ were determined with a commercially available competitive enzyme immunoassay kit (Catalog No 516351; Cayman Chemical Company, Ann Arbor, MI, USA) with inter- and intra-assay CV were $<20 \%$ and $<9.5 \%$ respectively, sensitivity $80 \%$. Colorimetric readings of absorbance were carried out using Perkin Elmer VICTOR X3 Multilabel Plate Reader serial number 20300255 (Perkin Elmer, Waltham, MA, USA).

Serum nitrate levels were evaluated as indicators of nitric oxide production by spectrophotometric measurements using the Griess reaction following conversion of nitrate to nitrite with nitrate reductase from Aspergillus spp. The values obtained by this procedure were the sum of nitrite plus nitrate, which are the stable end products of nitric oxide metabolism. Conditions were essentially as described by Moshage et al. (25) using absorbance readings at $540 \mathrm{~nm}$ recorded on a Multiskan EX microplate reader (Thermo Lab Systems, Helsinki, Finland).

\section{VDR SNPs genotyping}

The $V D R$ gene variants rs2228570 A>G (FokI), rs7975232 $\mathrm{C}>\mathrm{A}($ ApaI) and rs731236 $\mathrm{A}>\mathrm{G}($ TaqI) were analyzed in
DNA samples from 155 children. Genomic DNA was isolated from blood samples using the QIAamp DNA mini blood kit from Qiagen Hilden Germany (purchased at Izasa, Madrid, Spain) according to the manufacturer's instructions. DNA samples were amplified using a real time polymerase chain reaction (PCR) system QuantStudio 3 and 5 Real Time PCR System (Thermofisher Scientific, Waltham, MA, USA) with 384 wells, $0.1 \mathrm{~mL}$ per well qPCR Thermal Cyclers). A total of $2.5 \mu \mathrm{L}$ of template DNA was evaluated at a concentration of $5 \mu \mathrm{g} / \mathrm{mL}$ using standard cycling conditions; genotyping was performed using Taqman SNPs probes from Applied Biosystems (Life Technologies, Carlsbad, CA, USA). Genotyping and allelic discrimination were performed using QuantStudio Real Time PCR System Software (Thermofisher Scientific, Waltham, MA, USA).

\section{Statistical analysis}

The statistical software SNPStats (Institut Catalá d'Oncologia, Barcelona, Spain, available at https://www. snpstats.net/) was used to evaluate associations between the analytical parameters and $V D R$ SNPs. Allele frequency distribution and haplotype pattern were analyzed for Hardy-Weinberg equilibrium and linkage disequilibrium as unique populations.

Associations linking biochemical parameters, markers of inflammation and oxidative stress with the SNPgenotypes were determined using linear regression models that considered five modes of inheritance (codominant, dominant, recessive, additive, and overdominant). A $\mathrm{P}$ value $<0.05$ was considered statistically significant; the lowest Akaike and Bayesian information criterion assessment was applied. Multiple comparison test (Dunnett test) was made to avoid the false positive rate (error type I).

\section{Results}

The serum levels of biochemical, inflammatory and oxidative stress parameters evaluated in 155 children are summarized in Table 1. All values were within normal range including serum vitamin D levels. VDR SNPs FokI, ApaI and TaqI were successfully genotyped in more than $99 \%$ of the DNA samples and outcomes fit the Hardy-Weinberg equilibrium test $(\mathrm{P}>0.05)$. Linkage analysis revealed equilibrium between FokI and ApaI $\left(\mathrm{D}^{\prime}=0.29, \mathrm{r}^{2}=0.040\right)$ and TaqI $\left(\mathrm{D}^{\prime}=0.37, \mathrm{r}^{2}=0.036\right) \mathrm{SNPs}$ and disequilibrium between ApaI and TaqI $\left(\mathrm{D}^{\prime}=0.91, \mathrm{r}^{2}=0.452\right)$.

Comparisons among VDR SNPs and clinical and 
Table 1 Clinical, biochemical data and markers of inflammation and oxidative stress of children included in the study $(n=155)$

\begin{tabular}{lcc}
\hline & Mean & SEM \\
\hline Body mass index $\left(\mathrm{kg} / \mathrm{m}^{2}\right)$ & 18.4 & 0.4 \\
Systolic blood pressure $(\mathrm{mmHg})$ & 109 & 1.5 \\
Diastolic blood pressure $(\mathrm{mmHg})$ & 58 & 1.1 \\
Glucose $(\mathrm{mmol} / \mathrm{L})$ & 4.97 & 0.04 \\
Total cholesterol $(\mathrm{mmol} / \mathrm{L})$ & 4.13 & 0.05 \\
HDL-C $(\mathrm{mmol} / \mathrm{L})$ & 1.37 & 0.02 \\
Vitamin D (nmol/L) & 72.1 & 1.7 \\
Interleukin-6 $(\mathrm{pg} / \mathrm{mL})$ & 3.95 & 0.47 \\
TNF- $\alpha(\mathrm{pg} / \mathrm{mL})$ & 8.63 & 0.60 \\
Interferon- $\gamma(\mathrm{pg} / \mathrm{mL})$ & 1.26 & 0.12 \\
8-iso-PGF2 $\alpha(\mathrm{pg} / \mathrm{mL})$ & 63.6 & 6.8 \\
Nitrates $(\mu \mathrm{M})$ & 35.8 & 3.0 \\
\hline
\end{tabular}

8-iso-PGF2 $\alpha$, 8-isoprostaglandin F2 $\alpha$; HDL-C, high density lipoprotein cholesterol; SEM, standard error of the mean; TNF- $\alpha$, tumor necrosis factor- $\alpha$. experimental parameters revealed significant relationships with variables associated with lipid metabolism, inflammation and oxidative stress (Table 2). Specifically, quantitative analysis revealed that the homozygous major allele AA in the FokI SNP was associated with an increase in the levels of serum HDL-C $(0.17 \mathrm{mmol} / \mathrm{L})$ in a recessive inheritance mode $(\mathrm{P}=0.04)$. The minor allele $\mathrm{A}$ of $A p a I$ was significantly associated with diminished levels $(-1.97 \mathrm{pg} / \mathrm{mL}$ per allele) of serum TNF- $\alpha$ in an additive mode $(\mathrm{P}=0.02)$. An additive inheritance mode was also observed in the serum levels of 8 -iso-PGF2 $\alpha$ which were also significantly diminished $(-22.4 \mathrm{pg} / \mathrm{mL}$ per A allele; $\mathrm{P}=0.02)$. Dunnett test post hoc reveals significant results in the mutated genotypes respect to wild type concerning HDL-C levels $(\mathrm{P}=0.025)$ for FokI and decreasing 8-iso-PGF2 $\alpha(\mathrm{P}=0.02)$ and TNF- $\alpha$ ( $\mathrm{P}=0.016)$ levels for ApaI genotype.

When we analyzed data separately in males and females, we did not find gender-related differences. No significant associations were observed between TaqI SNP and any of the parameters evaluated in our study (data not shown).

Results associated with haplotype analysis for the three

Table 2 Vitamin D receptor polymorphisms association with biochemical, inflammatory and oxidative stress parameters in the children included in the study

\begin{tabular}{|c|c|c|c|c|c|c|}
\hline SNP ID & Parameter & Genotype & Mean (SEM) & Difference $(95 \% \mathrm{Cl})^{\dagger}$ & $\mathrm{P}$ & Best model \\
\hline \multirow{12}{*}{$\begin{array}{l}\text { rs2228570 Fokl } \\
A>G\end{array}$} & & $\mathrm{~A} / \mathrm{A}$ & $4.83(0.14)$ & & & \\
\hline & Total-C (mmol/L) & $\mathrm{G} / \mathrm{G}-\mathrm{A} / \mathrm{G}$ & $4.11(0.07)$ & $0.20(-0.21$ to 0.61$)$ & 0.35 & $\mathrm{R}$ \\
\hline & & $\mathrm{A} / \mathrm{A}$ & $4.30(0.16)$ & & & \\
\hline & & $\mathrm{A} / \mathrm{A}$ & $1.52(0.09)$ & & & \\
\hline & Vitamin D (nmol/L) & $\mathrm{G} / \mathrm{G}$ & $74.6(3.0)$ & $-3.5(-9.2$ to 2.3$)$ & 0.25 & A \\
\hline & & $\mathrm{A} / \mathrm{G}$ & $70.6(2.7)$ & & & \\
\hline & & A/A & $68.4(6.0)$ & & & \\
\hline & TNF- $\alpha(p g / m L)$ & G/G-A/G & $8.72(0.64)$ & $-0.34(-4.05$ to 3.56$)$ & 0.86 & $\mathrm{R}$ \\
\hline & & $\mathrm{A} / \mathrm{A}$ & $8.38(1.98)$ & & & \\
\hline & $\mathrm{IFN}-\gamma(\mathrm{pg} / \mathrm{mL})$ & $\mathrm{G} / \mathrm{G}$ & $1.35(0.27)$ & $-0.13(-0.50$ to 0.25$)$ & 0.51 & $A$ \\
\hline & & $\mathrm{A} / \mathrm{G}$ & $1.27(0.13)$ & & & \\
\hline & & $\mathrm{A} / \mathrm{A}$ & $1.05(0.17)$ & & & \\
\hline
\end{tabular}

Table 2 (continued) 
Table 2 (continued)

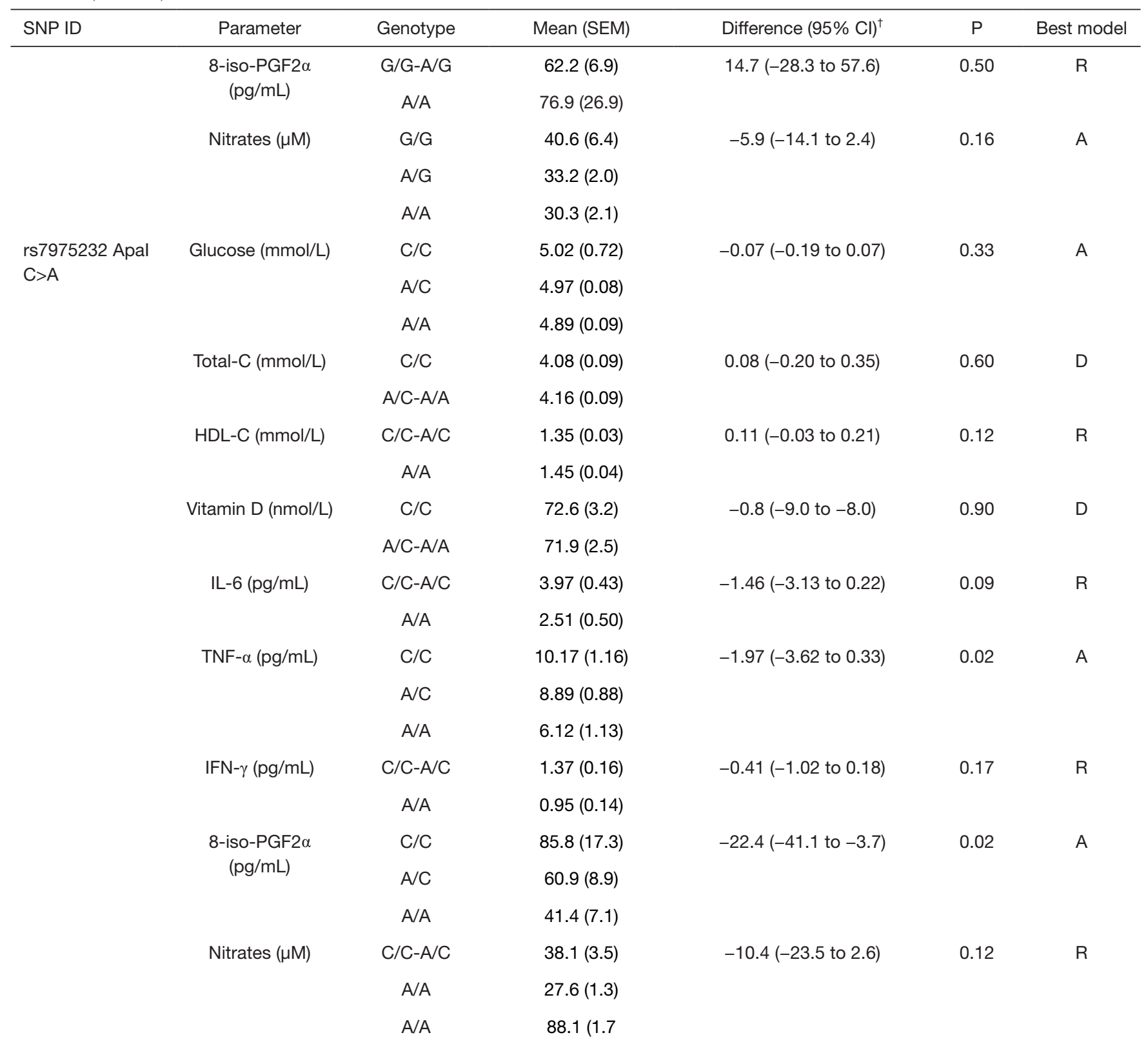

8-iso-PGF2 $\alpha$, 8-isoprostaglandin F2 $\alpha$; A, additive; Cl, confidence interval; D, dominant; HDL-C, high-density lipoprotein cholesterol; IFN- $\gamma$, interferon gamma; IL-6, interleukin-6; OD, overdominant; R, recessive; SEM, standard error of the mean; TNF- $\alpha$, tumor necrosis factor- $\alpha$; Total- $\mathrm{C}$, total cholesterol. ${ }^{\dagger}$ Maximum significative difference between means.

SNPs evaluated are as shown in Table 3. The differences in the experimental parameters were established with respect to the GCA haplotype for FokI, ApaI and TaqI, respectively, which was the most prevalent in this population, identified with a frequency of $32.3 \%$. Our results revealed that the ACA haplotype ( $24.8 \%$ frequency) was significantly associated with higher levels of HDL-C (an increase of 0.11 $\mathrm{mmol} / \mathrm{L}, \mathrm{P}=0.04$ ). The haplotype AAA (frequency $4.16 \%$ ) was significantly associated with diminished levels of TNF- $\alpha$ (a decrease of $6.0 \mathrm{pg} / \mathrm{mL}, \mathrm{P}=0.01$ ). It is also important to note the association of the haplotype GAA (FokI minor allele G, ApaI minor allele A, and TaqI major allele A) with 
Table 3 Haplotype analysis of vitamin D receptor polymorphisms in 155 children

\begin{tabular}{lcccccc}
\hline & $\begin{array}{c}\text { rs2228570 Fokl } \\
\text { A }>\text { G }\end{array}$ & $\begin{array}{c}\text { rs7975232 Apal } \\
\text { C>A }\end{array}$ & $\begin{array}{c}\text { rs731236 Taql } \\
\text { A }>\text { G }\end{array}$ & Frequency (\%) & $\begin{array}{c}\text { Difference } \\
(95 \% \text { Cl })^{\dagger}\end{array}$ & P \\
\hline HDL-C $(\mathrm{mmol} / \mathrm{L})$ & A & C & A & 24.8 & $0.11(0.00$ to 0.22$)$ & 0.04 \\
TNF- $\alpha(\mathrm{pg} / \mathrm{mL})$ & A & A & A & 4.2 & $-6.0(-10.8$ to -1.2$)$ & 0.01 \\
8-iso-PGF2 $\alpha(\mathrm{pg} / \mathrm{mL})$ & $\mathrm{G}$ & A & A & 11.6 & $-35.0(-67.4$ to -2.7$)$ & 0.03 \\
\hline
\end{tabular}

8-iso-PGF2 $\alpha$, 8-isoprostaglandin F2 $\alpha$; Cl, confidence interval, HDL-C, high density lipoprotein cholesterol; TNF- $\alpha$, tumor necrosis factor- $\alpha$. ${ }^{\dagger}$ Difference was established with respect to the GCA haplotype for Fokl, Apal and Taql.

parameters associated with oxidative stress. This haplotype was detected in nearly $11.6 \%$ of the participants in our study and was associated with diminished levels of 8 -isoPGF $2 \alpha$ (decrease of $35.0 \mathrm{pg} / \mathrm{mL}, \mathrm{P}=0.03$ ).

\section{Discussion}

Our findings have revealed direct relationships between the FokI and ApaI SNPs of the $V D R$ gene and parameters associated with lipid metabolism, inflammation and oxidative stress in children and adolescents who were vitamin $\mathrm{D}$ sufficient.

VDR regulates the major biological functions of vitamin $\mathrm{D}$; as such, we hypothesized that functional SNPs may have a direct impact on $V D R$ expression and susceptibility to conditions related to vitamin D metabolism. Many preclinical studies in animals with vitamin $\mathrm{D}$ deficiency or with genetically-silenced expression of $V D R$ have demonstrated that the alterations in the interactions between vitamin $\mathrm{D}$ and its receptor may result in chronic disorders and cardiovascular events (26). Although we identified no significant variation in vitamin D levels among the participants, patients with the FokI AA genotype had significantly higher levels of serum HDL-C. This finding was more evident in boys. As such, we hypothesize that this genotype may be associated with reduced risk of cardiovascular disease. HDL-C has a prominent role in reverse cholesterol transport; HDL-C particles have been associated with numerous additional protective aspects related to atherosclerosis, including antioxidative, antithrombotic, anti-inflammatory, metabolic and vasodilatory functions (27-29). HDL-C may also play a role in immune system modulation. FokI A>G (rs2228570) located in exon 2 of the $V D R$ gene is the only known $V D R$ SNP that results in two distinct VDR protein products; the A to $G$ conversion in the first translation initiation codon results in modifications of VDR protein structure (10).
The presence of the $G$ allele or F variant in the ATG translational start codon results in a protein that is missing three amino acids (424 amino acids); interestingly, this variant is more active than the longer form (427 amino acids) in terms of its transcription factor activity. The presence of the longer $V D R$ form (i.e., the A allele or $\mathrm{f}$ variant) with reduced transcriptional activity has been attributed to the absence of a functional VDR and may lead to increased levels of serum cholesterol and HDL-C (30). Our data are in agreement with the study of Filus et al. that focused on a population of individuals from Poland diagnosed with metabolic syndrome; the individuals with this same variant also had higher levels of serum HDL-C and reduced cardiovascular risk (31). Moreover, the FokI SNP GG genotype-FF variant has been associated with cardiovascular disease in adult population (32). By contrast, other studies found no relationship between FokI SNPs and serum lipid levels $(33,34)$. Taken together, our results suggest that the functional effects of FokI SNP might be gene and/or cell type-specific and may also be age- and gender-dependent. However, the mechanisms underlying modulation of serum HDL-C levels by VDR SNP remain unclear.

We further demonstrated that the A allele in ApaI SNP was associated with diminished levels of serum TNF- $\alpha$ and 8 -iso-PGF2 $\alpha$, which are markers of inflammation and oxidative stress respectively, in an additive mode of heritage. Serum levels of 8 -iso-PGF2 $\alpha$ represent an index of endogenous oxidative stress and provide evidence for the direct chemical impact of reactive oxygen species in biological systems. Inflammation plays a central role in a wide variety of physical and mental health problems and may also be a risk factor promoting the development of many cancers. Complex interactions between the oxidative stress and inflammatory pathways have been described in the literature. Reactive oxygen species can activate transcription factors including nuclear factor-kappa B 
$(\mathrm{NF}-\kappa \mathrm{B})$ and thereby increase expression of proinflammatory cytokines, including TNF- $\alpha$ (9). Vitamin $\mathrm{D}$ can inhibit this signaling pathway and thereby limit inflammation. In this study, we found that diminished levels of both TNF- $\alpha$ and 8-iso-PGF2 $\alpha$ were related to the ApaI SNP in children who were vitamin D sufficient. Thus, this genotype could contribute to protection of inflammatory processes. The ApaI SNP is located at intron 8 at the 3' untranslated region of the $V D R$ gene and has no impact on the amino acid sequence or structure of the VDR protein; however, it could alter the stability of the $V D R$ mRNA and/ or interfere with $V D R$ transcription. Untranslated regions can modulate levels of gene expression, most notably via regulation of mRNA stability. Reduced levels of mRNA stability and thus translation of the VDR protein will result in reduced responses to vitamin $\mathrm{D}$. In this sense, the $A p a I$ polymorphism may function as an intronic enhancer, it might mediate alternative splicing of the $V D R$ mRNA and/or be relevant as an enhancer that increases gene transcription.

Haplotype analysis suggested that the specific combinations of alleles from the FokI, ApaI and TaqI SNPs were associated with changes in lipid profile as well as in levels of inflammatory and oxidative mediators. Among these results, we identified a significant association between the ACA haplotype and elevated levels of serum HDL-C; this confirms their role with respect to modulation of lipid metabolism. By contrast, the AAA haplotype was associated with levels of serum TNF- $\alpha$ and the GAA haplotype with diminished levels of 8 -iso-PGF2 $\alpha$, to an even greater extent than that associated with ApaI individually. Thus, these haplotypes contribute to a lesser inflammation and oxidative stress. Previous studies have examined $V D R$ SNP haplotypes; they established that VDR haplotypes associated with FokI, BmsI, TaqI and ApaI SNPs could contribute significantly as a group over and above those mediates by VDR SNPs on an individual basis $(35,36)$. Our findings contribute to this group, and likewise suggest associations between $V D R$ haplotypes with inflammatory and oxidative stress markers. Moreover, it is true that linkage disequilibrium with one or more functional SNPs elsewhere in the $V D R$ gene might also serve to explain some of the associations observed.

There are several limitations with respect to this study that should be considered when interpreting our results. One limitation is the sample size. However, it is the consequence of the homogeneity of the population studied that was designed in order to limit bias and to increase the validity of results. One reason for the divergence between our results and those from other studies might be related to differences in homogeneity vs. heterogeneity of the other studied populations. We have studied specific haplotypes and these associations may be different in other haplotype contexts. Finally, this study focused exclusively on healthy Caucasian Spanish children with vitamin D sufficiency. It is well established that many factors as age, ethnicity and environment might affect not only vitamin effects but also VDR mRNA expression (37). Further studies will be needed to elucidate the importance of the observed genetic differences in other populations or conditions. Particularly studies in all the range of vitamin D levels might be highly informative.

\section{Conclusions}

In this study, we demonstrated significant associations of clinical parameters with known variants encoded by the VDR gene in children who were vitamin D sufficient. Among our findings, FokI has been associated with elevated levels of HDL-C and ApaI was associated with diminished levels of serum TNF- $\alpha$ and 8 -iso-PGF2 $\alpha$, which are markers of inflammation and oxidative stress, respectively. Moreover, specific haplotypes, including the ACA combination for FokI, ApaI and TaqI, were associated with changes in serum lipid profiles. Furthermore, the AAA haplotype was associated with serum levels of TNF- $\alpha$ and GAA with 8-iso-PGF2 $\alpha$. These results highlight the fact that specific $V D R$ polymorphisms may play a role in general susceptibility or protection to further degenerative diseases.

\section{Acknowledgments}

Funding: None.

\section{Footnote}

Reporting Checklist: The authors have completed the MDAR reporting checklist. Available at http://dx.doi.org/10.21037/ tp-20-198

Data Sharing Statement: Available at http://dx.doi. org/10.21037/tp-20-198

Conflicts of Interest: All authors have completed the ICMJE uniform disclosure form (available at http://dx.doi. 
org/10.21037/tp-20-198). The authors have no conflicts of interest to declare.

Ethical Statement: The authors are accountable for all aspects of the work in ensuring that questions related to the accuracy or integrity of any part of the work are appropriately investigated and resolved. The study was conducted in accordance with the Declaration of Helsinki (as revised in 2013). Ethical approval was obtained at the Ethical Committee of Dr. Peset University Hospital (Number CEIC 27/12). Written informed consent was obtained from parents or guardians of the children.

Open Access Statement: This is an Open Access article distributed in accordance with the Creative Commons Attribution-NonCommercial-NoDerivs 4.0 International License (CC BY-NC-ND 4.0), which permits the noncommercial replication and distribution of the article with the strict proviso that no changes or edits are made and the original work is properly cited (including links to both the formal publication through the relevant DOI and the license). See: https://creativecommons.org/licenses/by-nc-nd/4.0/.

\section{References}

1. Holick MF. The vitamin D deficiency pandemic: Approaches for diagnosis, treatment and prevention. Rev Endocr Metab Disord 2017;18:153-65.

2. Codoñer-Franch $P$, Tavárez-Alonso $\mathrm{S}$, Simó-Jordá R, et al. Vitamin D status is linked to biomarkers of oxidative stress, inflammation, and endothelial activation in obese children. J Pediatr 2012;161:848-54.

3. Vojinovic J. Vitamin D receptor agonists' antiinflammatory properties. Ann N Y Acad Sci 2014; 1317:47-56.

4. Yu F, Cui LL, Li X, et al. The genetic polymorphisms in vitamin $\mathrm{D}$ receptor and the risk of type 2 diabetes mellitus: an updated meta-analysis. Asia Pac J Clin Nutr 2016;25:614-24.

5. Lu S, Guo S, Hu F, et al. The Associations between the Polymorphisms of Vitamin D Receptor and Coronary Artery Disease: A Systematic Review and Meta-Analysis. Medicine (Baltimore) 2016;95:e3467.

6. Bakke D, Sun J. Ancient Nuclear Receptor VDR with New Functions: Microbiome and Inflammation. Inflamm Bowel Dis 2018;24:1149-54.

7. Shaikh F, Baig S, Jamal Q. Do VDR Gene Polymorphisms Contribute to Breast Cancer? Asian Pac J Cancer Prev
2016;17:479-83.

8. Akdogan N, Alli N, Incel Uysal P, et al. Role of serum 25-hydroxyvitamin $\mathrm{D}$ levels and vitamin $\mathrm{D}$ receptor gene polymorphisms in patients with rosacea: a case-control study. Clin Exp Dermatol 2019;44:397-403.

9. Hutchinson K, Kerley CP, Faul J, et al. Vitamin D receptor variants and uncontrolled asthma. Eur Ann Allergy Clin Immunol 2018;50:108-16.

10. Colombini A, Brayda-Bruno M, Ferino L, et al. Gender differences in the VDR-FokI polymorphism and conventional non-genetic risk factors in association with lumbar spine pathologies in an Italian case-control study. Int J Mol Sci 2015;16:3722-39.

11. Rai V, Abdo J, Agrawal S, et al. Vitamin D Receptor Polymorphism and Cancer: An Update. Anticancer Res 2017;37:3991-4003.

12. Al-Daghri NM, Mohammed AK, Al-Attas OS, et al. Vitamin D Receptor Gene Polymorphisms Modify Cardiometabolic Response to Vitamin D Supplementation in T2DM Patients. Sci Rep 2017;7:8280.

13. Mohammadi A, Khanbabaei H, Nasiri-Kalmarzi R, et al. Vitamin D receptor ApaI (rs7975232), BsmI (rs1544410), Fok1 (rs2228570), and TaqI (rs731236) gene polymorphisms and susceptibility to pulmonary tuberculosis in an Iranian population: A systematic review and meta-analysis. J Microbiol Immunol Infect 2020;53:827-35.

14. Filgueiras MS, Rocha NP, Novaes JF, et al. Vitamin D status, oxidative stress, and inflammation in children and adolescents: A systematic review. Crit Rev Food Sci Nutr 2020;60:660-9.

15. Parsanathan R, Jain SK. Novel Invasive and Noninvasive Cardiac-Specific Biomarkers in Obesity and Cardiovascular Diseases. Metab Syndr Relat Disord 2020;18:10-30.

16. Jain SK, Parsanathan R, Achari AE, et al. Glutathione Stimulates Vitamin D Regulatory and Glucose-Metabolism Genes, Lowers Oxidative Stress and Inflammation, and Increases 25-Hydroxy-Vitamin D Levels in Blood: A Novel Approach to Treat 25-Hydroxyvitamin D Deficiency. Antioxid Redox Signal 2018;29:1792-807.

17. Parsanathan R, Jain SK. Glutathione deficiency induces epigenetic alterations of vitamin $\mathrm{D}$ metabolism genes in the livers of high-fat diet-fed obese mice. Sci Rep 2019;9:14784.

18. Bahrami A, Sadeghnia HR, Tabatabaeizadeh SA, et al. Genetic and epigenetic factors influencing vitamin D status. J Cell Physiol 2018;233:4033-43.

19. Dai J, Lv ZT, Huang JM, et al. Association between 
polymorphisms in vitamin $\mathrm{D}$ receptor gene and adolescent idiopathic scoliosis: a meta-analysis. Eur Spine J 2018;27:2175-83.

20. Smith TJ, Lanham-New SA, Hart KH. Vitamin D in adolescents: Are current recommendations enough? J Steroid Biochem Mol Biol 2017;173:265-72.

21. Lee C. Controversial Effects of Vitamin D and Related Genes on Viral Infections, Pathogenesis, and Treatment Outcomes. Nutrients 2020;12:962.

22. Linden MA, Freitas RGBON, Hessel G, et al. Definition of vitamin $\mathrm{D}$ deficiency in schoolchildren: systematic review with meta-analysis. Arq Gastroenterol 2019;56:425-30.

23. Holick MF, Binkley NC, Bischoff-Ferrari HA, et al. Evaluation, treatment, and prevention of vitamin D deficiency: an Endocrine Society clinical practice guideline. J Clin Endocrinol Metab 2011;96:1911-30.

24. Spiro A, Buttriss JL. Vitamin D: An overview of vitamin D status and intake in Europe. Nutr Bull 2014;39:322-50.

25. Moshage H. Simple and reliable measurement of nitric oxide metabolites in plasma. Clin Chem 2009;55:1881-2.

26. Bouillon R, Carmeliet G, Verlinden L, et al. Vitamin D and human health: lessons from vitamin $\mathrm{D}$ receptor null mice. Endocr Rev 2008;29:726-76.

27. März W, Kleber ME, Scharnagl H, et al. HDL cholesterol: reappraisal of its clinical relevance Clin Res Cardiol 2017;106:663-75.

28. Kontush A. HDL-mediated mechanisms of protection in cardiovascular disease. Cardiovasc Res 2014;103:341-9.

29. Nicholls SJ, Nelson AJ. HDL and cardiovascular disease. Pathology 2019;51:142-7.

30. Li S, He Y, Lin S, et al. Increase of circulating cholesterol

Cite this article as: Ferrer-Suay S, Alonso-Iglesias E, Tortajada-Girbés M, Carrasco-Luna J, Codoñer-Franch P. Vitamin D receptor gene ApaI and FokI polymorphisms and its association with inflammation and oxidative stress in vitamin D sufficient Caucasian Spanish children. Transl Pediatr 2021;10(1):103-111. doi: 10.21037/tp-20-198 in vitamin $\mathrm{D}$ deficiency is linked to reduced vitamin $\mathrm{D}$ receptor activity via the Insig-2/SREBP-2 pathway. Mol Nutr Food Res 2016;60:798-809.

31. Filus A, Trzmiel A, Kuliczkowska-Płaksej J, et al. Relationship between vitamin D receptor BsmI and FokI polymorphisms and anthropometric and biochemical parameters describing metabolic syndrome. Aging Male 2008;11:134-9.

32. He L, Wang M. Association of vitamin d receptor-a gene polymorphisms with coronary heart disease in Han Chinese. Int J Clin Exp Med 2015;8:6224-9.

33. Turhan T, Doğan HO, Boğdaycioğlu N, et al. Vitamin D status, serum lipid concentrations, and vitamin $\mathrm{D}$ receptor (VDR) gene polymorphisms in Familial Mediterranean fever. Bosn J Basic Med Sci 2018;18:21-8.

34. Jia J, Tang Y, Shen C, et al. Vitamin D receptor polymorphism rs2228570 is significantly associated with risk of dyslipidemia and serum LDL levels in Chinese Han population. Lipids Health Dis 2018;17:193.

35. Razi F, Meshkani MA, Zarrabi F, et al. Haplotypes in vitamin $\mathrm{D}$ receptor gene encode risk in diabetic nephropathy. Gene 2019;683:149-52.

36. Rodrigues Simões TM, da Silva R, Bianco B, et al. Vitamin D Levels, Frequency of Vitamin D Receptor Gene Polymorphisms, and Associations with Overweight and Asthma in Brazilian Schoolchildren. Ann Nutr Metab 2019;75:238-45.

37. Meyer V, Saccone DS, Tugizimana F, et al. Methylation of the vitamin $\mathrm{D}$ receptor (VDR) gene, together with genetic variation, race, and environment influence the signaling efficacy of the toll-like receptor 2/1-VDR pathway, Front Immunol 2017;8:1048. 